\title{
Bacteriocinogenic Activity in the Genus Cellvibrio
}

\author{
By G. HALLIWELL AND C. SWEET* \\ Sub-Department of Microbiology, Department of Botany and Microbiology, \\ University College, Swansea
}

(Received 8 January 1973; revised I3 March I973)

\section{SUMMARY}

The production and characteristics of a new bacteriocin, cellvibriocin, are described. Of ten known strains of Cellvibrio examined six were cellvibriocinogenic. Cellvibriocin produced by Cellvibrio sp. 9916 appeared most specific on most media and was studied in detail. It was thermolabile, unaffected by deoxyribonuclease, ribonuclease, lysozyme and catalase but completely inactivated by proteases and protein denaturants such as chloroform, acetone and ethanol. Although not readily detectable nor inducible in liquid culture cellvibriocin was induced on solid (agar) media by ultraviolet light; it was not extractable from agar grown cultures by buffer solutions or by freeze-thawing, or from liquid grown cultures lysed with ethylene diaminotetraacetic acid and lysozyme or from cultures disintegrated by ultrasonication, in a Hughes's press, with butanol or with alumina.

\section{INTRODUCTION}

Isoantagonism produced by related bacterial strains of Escherichia coli as a result of the formation of highly specific lethal substances was demonstrated as early as 1925 by Gratia (I925). More recently Fredericq (1957) described antibiotic substances, colicins, produced by $E$. coli; similar compounds are produced also by many shigellas, some $E$. freundii and a few salmonellas. Other 'Bacteriocins' (Jacob, Lwoff, Siminovitch \& Wollman, I953), also with isoantagonistic properties, have been found in additional genera (Bradley, 1967; Hamon, 1964; Reeves, 1965) but not so far in the genus Cellvibrio. We now describe the production of a new bacteriocin, cellvibriocin, by the genus Cellvibrio, soil organisms of considerable importance in nature in contributing to the carbon cycle through the turnover of cellulose.

\section{METHOD}

Organisms and growth conditions. Unless designated QM (Quatermaster Laboratories, Natick, Massachusetts, U.S.A.), NCTC (National Collection of Type Cultures) or NCDO (National Collection of Dairy Organisms) the cellulolytic and non-cellulolytic bacteria used were obtained from the National Collection of Industrial Bacteria. All were subcultured at monthly intervals. Cellulolytic bacteria comprised Cellvibrio vulgaris strains QM-BI, -B4, -BI 22, -8975; C. fulvus strains QM-BI 8, -8634; Cellvibrio spp. 9913, 9914, 991 5, 9916; strains (Cs) were Cellvibrio spp. iolated locally. All were grown at $25{ }^{\circ} \mathrm{C}$ on slopes of the basal Agar Medium solidified with I \% agar (Oxoid, no. 3) and with a strip of filter paper (Whatman no. I) as sole available carbon source. Extensive growth occurred after one week; slopes were then maintained at room temperature. Double strength basal medium contained $(\mathrm{g} / \mathrm{l})$; $\mathrm{NaNo}_{3}, 4 \cdot 0 ; \mathrm{MgSO}_{4} \cdot 7 \mathrm{H}_{2} \mathrm{O}, \mathrm{I} \cdot 0 ; \mathrm{Fe}_{2}\left(\mathrm{SO}_{4}\right)_{3}, 0 \cdot 02 ; \mathrm{KCl}, \mathrm{I} \cdot 0 ; \mathrm{KH}_{2} \mathrm{PO}_{4}, 0 \cdot 3 ; \mathrm{K}_{2} \mathrm{HPO}_{4}$, I·4;

\footnotetext{
* Present address: Department of Microbiology, University of Birmingham.
} 
(basal salts, H. S. Levinson, personal communication) with yeast extract (Oxoid), 0.04. It was adjusted to $\mathrm{pH} 7 \cdot \mathrm{I}$ with $\mathrm{M}-\mathrm{NaOH}$ before sterilization by filtration. Soluble carbon sources used with this medium were $0.05 \%$ glucose, $1 \%$ starch and $0.5 \%$ casein hydrolysate (Oxoid). Dilute nutrient broth-agar medium was prepared by diluting nutrient broth 12 -fold with basal growth medium (single strength) and adding glucose $0.05 \%(w / v)$ and $\mathrm{I} \%(\mathrm{w} / \mathrm{v})$ agar. Noncellulolytic cultures, grown on nutrient agar at $30^{\circ} \mathrm{C}$ unless indicated otherwise, comprised Arthrobacter ureafaciens 78I I, Bacillus megaterium NCDO 685, B. subtilis NCDO 736, Brevibacterium helvolum $8717\left(25^{\circ} \mathrm{C}\right)$, Escherichia coli $8277\left(37^{\circ} \mathrm{C}\right)$, Klebsiella aerogenes NCTC 8192 , Micrococcus flavus 8I66 $\left(25^{\circ} \mathrm{C}\right)$, M. lysodeikticus $9278\left(37^{\circ} \mathrm{C}\right)$, Mycobacterium phlei NCTC 8I 5I, M. smegmatis NCTC 333, Nocardia globerula NCTC $8862\left(25^{\circ} \mathrm{C}\right)$, Proteus vulgaris NCTC 4636 , Pseudomonas fragii NCDO $752\left(25^{\circ} \mathrm{C}\right)$, Sarcina lutea $8553\left(25^{\circ} \mathrm{C}\right)$, Serratia marcescens NCTC $8706\left(25^{\circ} \mathrm{C}\right)$, Shigella sonei NCTC $8220\left(37^{\circ} \mathrm{C}\right)$ and Staphylococcus aureus $8244\left(37^{\circ} \mathrm{C}\right)$.

\section{Cellvibriocin detection}

Plate assay. This was based on the plate-overlay method of Fredericq (1957). Streaks of potential producer strains on various media in Petri dishes were incubated at $25^{\circ} \mathrm{C}$ for $48 \mathrm{~h}$. A $24 \mathrm{~h}$ culture ( $0 . \mathrm{I} \mathrm{ml}$ ) of indicator strain suspended in $5 \mathrm{ml}$ of melted soft agar medium (the same medium as the first layer but containing only $0.7 \%$ agar) was then seeded over the entire surface. The 'lawn' developed by the indicator strain after $48 \mathrm{~h}$ of incubation at $25^{\circ} \mathrm{C}$ revealed the presence of cellvibriocin in the development of inhibition zones around the streak. The zones were recorded in $\mathrm{mm}$ as the mean of eight replicates. The absence of bacteriophage activity was shown by transferring material from inhibition zones into liquid medium containing exponentially growing indicator cells. After incubating, the supernatant phase obtained by centrifuging was assayed for bacteriophage.

Spot assay was used to detect bacteriocin in liquid cultures. Serial twofold dilutions $(0.03 \mathrm{ml})$ of centrifuged culture fluids were spotted on to plates seeded previously with an indicator strain. After incubating, the plates were examined for inhibition of growth. The titre, in arbitrary units $/ \mathrm{ml}$, was that given by the reciprocal of the highest dilution showing complete inhibition of the sensitive indicator strain.

Properties of the bacteriocin. These were examined with streaks of celvibriocin 9916 which were subjected to various treatments prior to the Plate Assay. Ability to pass through membranes (dialysis of Visking Co., U.S.A.; filter membranes of Oxoid; cellophane jar covers, Boots Ltd, Swansea) was tested by placing sterile membranes over the streaks before overlaying with indicator strain. Streaked plates, previously incubated at $25^{\circ} \mathrm{C}$ for $48 \mathrm{~h}$ were tested for susceptibility of cellvibriocin to heat in a hot air oven at $50^{\circ} \mathrm{C}$ for 20 $\mathrm{min}$. Organic solvents on filter paper were placed in the lid of inverted streaked plates, the bacteriocin was exposed for $30 \mathrm{~min}$ at $25^{\circ} \mathrm{C}$ before the paper was removed, excess vapour allowed to evaporate for $\mathrm{I} h$, and the indicator strain applied.

The action of various enzymes on cellvibriocin was examined using strips of sterile glass fibre paper (grade GF/A, Whatman) soaked in the enzyme preparation and placed at right angles across the producer streak (Brubaker \& Surgalla, 196I). Incubation for $3 \mathrm{~h}$ at $25^{\circ} \mathrm{C}$ permitted sufficient enzymatic action before the strip was removed and the indicator strain was added. DNase (Type I, from bovine pancreas, $\mathrm{I} \times$ crystallized and lyophilized: Sigma Chemical Co., St Louis, Missouri, U.S.A.), RNase (Type IA, from bovine pancreas, $5 \times$ crystallized: Sigma), trypsin (crystallized from bovine pancreas: Armour Laboratories, Eastbourne, Sussex), lysozyme (Armour Laboratories), pronase (B grade, 45,000 PUK units/ g: Calbiochem, La Jolla, California, U.S.A.), and catalase (B.D.H., Poole, Dorset), were tested. 
Induction of bacteriocin synthesis. Streak cultures grown for $48 \mathrm{~h}$ were irradiated in the dark at a distance of $\mathrm{I} 6 \mathrm{~cm}$ with u.v. light at $2537 \AA$ for $10 \mathrm{~s}$ to $5 \mathrm{~min}$ and then reincubated for $24 \mathrm{~h}$ before overlaying with the indicator strain. With liquid cultures, cells from early and late exponential phase were distributed into dishes to a depth of $2 \mathrm{~mm}$ irradiated similarly for Io to I $20 \mathrm{~s}$, before reincubating at $25{ }^{\circ} \mathrm{C}$ for $24 \mathrm{~h}$. Culture fluids were assayed for cellvibriocin by 'Spot Assay'.

Exponential phase cultures were also treated with mitomycin-C (Sigma) ( $0 . \mathrm{I}$ to $\mathrm{I} \cdot 0 \mu \mathrm{g} / \mathrm{ml}$ ) for 10 min at $25^{\circ} \mathrm{C}$ before the medium was removed by centrifuging. The cells were resuspended in fresh medium and incubated for a further $24 \mathrm{~h}$ before assay. Induction of cellvibriocin was also attempted with 0.025 to $\mathrm{I} \cdot 76 \mathrm{~mm}-\mathrm{H}_{2} \mathrm{O}_{2}$ (Stickler, Tucker \& Kay, I965), by cold shock and by anaerobiosis (Farkas-Himsley \& Seyfried, 1963a).

Attempted extraction of bacteriocin. Cultures on agar were thoroughly dispersed with a glass spreader and then extracted with $20 \mathrm{ml}$ of either (i) buffer solutions ranging from $\mathrm{pH} 3$ to 9 or (ii) fresh liquid medium after first treating cultures with (and without, for control sets) u.v. light to induce the bacteriocin. Other cultures on agar were extracted by freezing at $-\mathrm{I} 5{ }^{\circ} \mathrm{C}$ for $\mathrm{I} 6 \mathrm{~h}$ folowed by rapid thawing for $4 \mathrm{~h}$ at $25^{\circ} \mathrm{C}$. In each case the exuded fluid was centrifuged and assayed by the 'Spot Assay'. Other samples of the same cellvibriocinogenic cells were lysed with lysozyme $(0 \cdot \mathrm{Img} / \mathrm{ml})$ and EDTA $(2 \mathrm{mg} / \mathrm{ml})$. The insoluble and soluble fractions obtained by centrifuging at $20000 \mathrm{~g}$ were tested for bacteriocin activity. Cells were also disintegrated with butanol, with alumina (Halliwell, 1957), with $\mathrm{NaCl}$ (Herschmann \& Helinski, I967) and in a press (Hughes, 195I) and the fractions tested for bacteriocin activity.

\section{RESULTS}

On glucose-casein hydrolysate-agar medium four of the ten strains of Cellvibrio tested were cellvibriocinogenic, namely 9915, 9916, QM-B I and QM-B4 (Table I); none had the same spectrum of activity.

Strain QM-BI was the most specific, strain QM-B4 offered the broadest spectrum, and strains 9915 and 9916 showed intermediate activity. On the same medium five of the ten catalogued strains (see Methods) of Cellvibrio tested for sensitivity were unaffected by the bacteriocin(s). The isolates of Cellvibrio obtained locally (Cs strains, see Methods) differed from one another in one or two minor properties but in their susceptibilities to producer strains 9915, 99I6 QM-BI and QM-B4 fitted readily into the six groups (cs) listed in Table I. In their properties and susceptibility to cellvibriocin, isolates CSI 4 and 33 were identical to Cellvibrio spp. 8634 and QM-BI respectively.

Synthesis of cellvibriocin by some species was promoted on dilute nutrient broth-agar compared with the casein hydrolysate medium of the earlier experiments. The antimicrobial spectrum of the three strains 9914, 9915 and 9916 (Table 2), active on that medium, showed an increased spectrum of activity against Cellvibrio spp. All the seven other strains of Cellvibrio (see Methods) tested for bacteriocin production on this medium were inactive. Strains 9913 and QM-BI 8 also failed to respond as sensitive organisms. Of seventeen noncellulolytic cultures tested (see Methods), sensitivity to cellvibriocin action was relatively feeble and confined to four genera (Table 2). Strain 9914, a non-producer of bacteriocin on casein hydrolysate medium of Table I and strain 9915 were self inhibitory.

The possibility that inhibition arose from more general effects such as staleing of medium or peroxide formation was excluded in parallel experiments by destroying the activity once formed with chloroform. Furthermore, strains 9914 and 991 5 had powerful catalase activity. Neither did inhibition arise from the formation of acid or alkali in the culture since the area 
Table I. Bacteriocinogenic activity of Cellvibrio spp. against different strains of Cellvibrio used as indicators

Producer strains (Cellvibrio spp. 99I5, 99I6, QM-BI and QM-B4) were streaked on the Basal Agar Medium supplemented with $0.05 \%$ glucose, $0.5 \%$ casein hydrolysate and $0.0 \mathrm{I} \mathrm{M}-\mathrm{CaCl}_{2}$ and incubated for $48 \mathrm{~h}$ at $25^{\circ} \mathrm{C}$ before adding the indicator strains in soft agar $(0.7 \%)$ of the same medium. After incubating for a further $48 \mathrm{~h}$ at $25^{\circ} \mathrm{C}$ bacteriocin activity was expressed as the size of the inhibition zone in $\mathrm{mm},(-)$ is no inhibition.

\begin{tabular}{|c|c|c|c|c|}
\hline \multirow{2}{*}{$\begin{array}{l}\text { Indicator } \\
\text { strains }\end{array}$} & \multicolumn{4}{|c|}{ Bacteriocinogenic activity of Cellvibrio spp. } \\
\hline & 9915 & 9916 & QM-BI & QM-B4 \\
\hline \multicolumn{5}{|c|}{ Cellvibrio spp. } \\
\hline 9914 & 5 & 3 & - & 3 \\
\hline 8634 & - & 4 & - & 4 \\
\hline QM-BI & 9 & 6 & 5 & - \\
\hline QM-B4 & 4 & - & - & - \\
\hline QM-BI 22 & - & 5 & - & 4 \\
\hline CS 13 & 3 & - & 18 & 3 \\
\hline $\operatorname{cs~} 16$ & I 5 & - & - & 5 \\
\hline CS I7 & 9 & 4 & 18 & 4 \\
\hline CS 18 & - & - & 6 & 5 \\
\hline CS 19 & 7 & 6 & - & - \\
\hline CS 3I & - & - & - & 6 \\
\hline
\end{tabular}

Table 2. Promotion of cellvibriocin formation on enriched medium by producer strains of Cellvibrio acting on Cellvibrio and on other spp.

Producer organisms (Cellvibrio spp. 9914, 9915 and 9916) were grown on a solid medium of dilute nutrient broth and agar (see Methods). Cultures were incubated for $48 \mathrm{~h}$ at $25^{\circ} \mathrm{C}$ before adding the indicator organisms in soft agar (Table I). Bacteriocinogenic activity measured as in Table $\mathrm{I}$.

$\quad \begin{aligned} & \text { Indicator } \\ & \text { strains }\end{aligned}$
Cellvibrio spp.
9914
9915
9916
8634
8975
QM-BI
QM-B4
QM-BI 22
Other spp.
Bacillus megaterium
B. subtilis
Nocardia globerula
Staphylococcus aureus

$\begin{array}{ccc}\text { Bacteriocinogenic activity of Cellvibrio spp. } \\ \text { 9914 } & 99 \text { I } 5 & 99 \text { I6 } \\ \text { I2 } & \text { I7 } & 6 \\ \text { I8 } & \text { I5 } & - \\ \text { I4 } & \text { I } 4 & 3 \\ \text { II } & \text { I0 } & 5 \\ \text { I4 } & \text { I3 } & 4 \\ \text { I2 } & \text { I2 } & 4 \\ \text { II } & \text { I2 } & 2 \\ \text { I2 } & \text { I4 } & \\ & & - \\ 4 & 4 & - \\ 4 & 3 & - \\ 3 & 3 & \end{array} 4$

surrounding the streaks registered $\mathrm{pH} 8.0$ for both producer and non-producer strains, a level tolerated well by all the indicator organisms tested. Bacteriophages were not involved since material from the zones of inhibition was non-infective.

With some strains occasional inconsistencies in bacteriocin formation appeared to be associated with certain batches of casein hydrolysate. This was overcome to a considerable extent by substituting starch for casein hydrolysate in the medium (Table 3). Producer strain 9916 again appeared to show a somewhat greater specificity, being active against only three of the eight Cellvibrio spp. and more particularly against strain 99I5. Three of the 
Table 3. Sensitivity of Cellvibrio strains to bacteriocins produced by these strains grown on Basal Agar Medium supplemented with (a) I \% soluble starch, (b) I \% soluble starch with $0.0 \mathrm{I} \mathrm{M}-\mathrm{CaCl}_{2}$ and $(\mathrm{c}) \mathrm{I} \%$ soluble starch with $0.5 \%$ casein hydrolysate $0.0 \mathrm{I} \mathrm{M}-\mathrm{CaCl}_{2}$ agar media.

Other details as in Table $\mathbf{I}$.

\begin{tabular}{|c|c|c|c|c|c|c|c|c|c|c|c|c|c|c|c|}
\hline \multirow[b]{3}{*}{$\begin{array}{l}\text { Indicator } \\
\text { strains }\end{array}$} & \multicolumn{15}{|c|}{ Bacteriocinogenic activity of Cellvibrio spp. } \\
\hline & \multicolumn{3}{|c|}{$\underbrace{9914}$} & \multicolumn{3}{|c|}{$\overbrace{}^{9915}$} & \multicolumn{3}{|c|}{$\overbrace{}^{9916}$} & \multicolumn{3}{|c|}{$\underbrace{8634}$} & \multicolumn{3}{|c|}{$\underbrace{Q M-B I}$} \\
\hline & (a) & $\overbrace{(b)}$ & (c) & (a) & $\overbrace{(b)}$ & (c) & (a) & $(b)$ & (c) & (a) & $(b)$ & (c) & (a) & $\overbrace{(b)}$ & (c) \\
\hline 9914 & 9 & $\mathbf{I} 2$ & - & 8 & 9 & - & 3 & 3 & 3 & - & - & - & - & - & 3 \\
\hline 9915 & 19 & 14 & 3 & 8 & 7 & - & 8 & 8 & 4 & I & - & 3 & - & - & 5 \\
\hline 9916 & 12 & 10 & 5 & 12 & 8 & 3 & - & - & - & - & 2 & - & - & $\longrightarrow$ & 7 \\
\hline 8634 & 9 & 7 & I & 一 & - & 二 & $\longrightarrow$ & 一 & - & 一 & - & - & - & - & 8 \\
\hline 8975 & I I & 10 & 8 & 10 & 10 & 8 & 一 & - & - & - & - & - & - & - & - \\
\hline QM-BI & IO & 8 & 6 & 9 & 8 & - & - & - & - & 4 & 2 & 2 & - & - & - \\
\hline QM-B4 & 10 & I 2 & 8 & I2 & 8 & 6 & 一 & 一 & 一 & 一 & I I & 一 & $一$ & 一 & - \\
\hline QM-BI 22 & 15 & IO & 13 & 15 & 10 & 10 & 5 & 2 & 2 & - & 5 & - & 一 & 一 & 一 \\
\hline
\end{tabular}

six local cellulolytic isolates (CS strains of Table 1 ) were susceptible to strain 99I6 when tested on the starch-agar medium ( $a$ of Table 3). Strains 9914 and 9915 inhibited almost all strains in all media and in general, like strain 9916 , showed less activity in presence of casein hydrolysate (Table 3, Column $c$ ). In contrast this medium alone proved effective for strain QM-BI, as had been observed previously on the glucose-casein hydrolysate agar medium of Table I. Calcium ions provided a varied response related mainly to the indicator strain (Table 3). Here the absence of $\mathrm{Ca}^{2+}$ (medium $a$ compared with $b$ ) was of some interest in enhancing cellvibriocin activity of producer strain 9915 against the indicator strain QM-BI 22; producer strain 9914 reacted likewise against the same strain (QM-BI22).

Biosynthesis of cellvibriocin was an unstable characteristic of certain strains, being lost on repeated subculture on certain media. On the glucose-casein hydrolysate-agar medium of Table I, for example, producer strains 99I6 and QM-B4 ultimately failed to synthesize bacteriocin and, although producer strain 9916 still displayed this activity on other media (Tables 2 and 3), QM-B4 failed to regain this property under any conditions.

With some streak cultures, particularly strain 9916, u.v. irradiation after growth for $40 \mathrm{~h}$ promoted bacteriocin synthesis, illustrated by an increase in the size of the inhibition zone formed against the indicator strain. Attempts to induce cellvibriocin synthesis in streak cultures by 'cold shock' treatment (see Methods) were ineffective; the same treatment or that with mitomycin-C, $\mathrm{H}_{2} \mathrm{O}_{2}$, and anaerobiosis were also unsuccessful with liquid cultures. The bacteriocin was non-extractable from agar cultures or from liquid grown cellvibriocinogenic cells. Strains 99I6 and QM-B4 retained the bacteriocin in the insoluble material after ultrasonication, almost wholly in the membrane fraction as shown in parallel experiments involving separation of cell fractions obtained after lysis with EDTA and lysozyme in buffered sucrose. A variety of other procedures (see Methods) used to try to dislodge cell vibriocin from cells of agar or liquid grown cultures were also ineffective.

Protein nature of cellvibriocin. Cellvibriocin 9916 passed readily through a filter membrane of porosity $0.45 \mu \mathrm{m}$ and to some extent through dialysis tubing and cellophane though this probably arose from the known cellulolytic action of cellvibrio on the last two membranes. Compared with unheated control samples approximately $70 \%$ of the bacteriocinogenic activity on agar was lost after exposure to $50{ }^{\circ} \mathrm{C}$ for $20 \mathrm{~min}$; cellvibriocin from strains 9I 49 
and 9915 behaved similarly, that from strain 8634 lost all activity under these conditions. Cellvibriocin 9916 was inactivated in $30 \mathrm{~min}$ at $25^{\circ} \mathrm{C}$ by the vapour of acetone, amyl alcohol, benzene, butanol, chloroform, ether, ethanol, methanol and propanol. Lysozyme, catalase, RNase and DNase had no effect on the activity of this cellvibriocin whereas the proteases trypsin and pronase caused considerable inactivation. In short periods of exposure $(3 \mathrm{~h})$ of the bacteriocin to the last two enzymes impregnated in glass fibre paper (prior to its removal and addition of the indicator strain) the inhibition zone due to cellvibriocin disappeared completely in areas exposed to the enzyme. Sensitivity to proteolytic enzymes could be demonstrated more dramatically by streaking a protease producing bacterium (isolate CS 22 from local soils) at right angles to a cellvibriocinogenic strain (9916) and incubating for $48 \mathrm{~h}$ at $25^{\circ} \mathrm{C}$. This permitted active secretion of enzyme as well as of cellvibriocin into the medium before seeding with the indicator strain 991 5 . The longer exposure and continued production of protease clearly showed complete destruction of cellvibriocin activity in a path at least $3 \mathrm{~mm}$ wide on both sides of the proteolytic bacterium. Non-proteolytic isolates showed no such effect.

\section{DISCUSSION}

Of the several Cellvibrio spp. examined as producers of cellvibriocin, strains 9914, 9915 and 9916 possessed the greatest activity against most other Cellvibrio spp. (Table 2) whilst relatively feeble activity was shown against species outside this genus. Strain 9916 appeared to have slightly greater specificity in failing to recognize as many sensitive strains (Tables 2 and 3). Apparently cellvibriocins from strains 9914 and 9915 are of the type active also against some unrelated genera as found with colicins from Escherichia coli (Cook, Blackford, Robbins \& Parr, 1953), with monocins from Listeria monocytogenes (Hamon \& Peron, 1962) and with vibriocin from Vibrio comma (Farkas-Himsley \& Seyfried, 1963 $b$ ). Further, Cellvibrio strains 9914 and 9915 produced bacteriocins which, like megacins (Ivanovics, 1962) and the bacteriocins of Group A streptococci (Kuttner, I966) act against themselves (Table 2).

Whereas on agar medium diffusion of bacteriocin away from producer cells permitted its ready detection and estimation, in liquid culture its liberation or accumulation was small as judged by the 'Spot Assay' method used. 'Spot Assays' of, for example, extracts of whole cells or the insoluble matter of ultrasonicated cells provided clear symmetrical zones of inhibition free from viable cells (even on prolonged incubation) but at best represented activities of not more than 10 to $20 \mathrm{units} / \mathrm{ml}$. In this respect cellvibriocin resembles colicin in which $90 \%$ of the activity remains cell bound (Herschmann \& Helinski, 1967; Timmis, 1972) or vibriocin detectable on agar plates but not in cell-free systems (Takeya \& Shimodori, I969), possibly because it is adsorbed to its producer strain (Jayawardene \& FarkasHimsley, 1969). Other examples are the megacins B and C which either cannot be detected in liquid culture or which disappear rapidly from culture fluids after the early exponential phase of growth (Holland \& Roberts, 1964).

As far as we are aware this is the first indication of bacteriocinogenic activity in cellulolytic organisms apart from a briet report by Tchan \& Giuntini (I950) of a possible myxococcin (?) in a Sporocytophaga species. The fairly wide distribution of cellvibriocin throughout the genus Cellvibrio may serve to explain earlier observations with such bacteria (Halliwell, I965), where after growth on certain media some species lost much of their cellulolytic potential. Residual viable cells were severely handicapped in their attempts to elaborate the enzymes necessary to attack the normal insoluble substrate cellulose whilst remaining unimpaired in their utilization of simpler soluble derivatives. One possibility suggests itself 
from the role of limited nitrogen in promoting cellvibriocin production by, for example, strains 9914 and 9915 (Table 3 , treatments $a$ and $c$ ). Ecologically such action may serve the community by confining the synthesis of inducible enzymes and colony development during adverse conditions. If such a system should prove general in nature it would provide an interesting variant of metabolic control in the cellulose system.

We thank the Science Research Council for a grant to C.S.

\section{REFERENCES}

BraDley, D. E. (1967). Ultrastructure of bacteriophages and bacteriocins. Bacteriological Reviews $3 \mathbf{r}$, $230-3 I 5$.

Brubaker, R. R. \& Surgalla, M. J, (I96I). Pesticins. I. Pesticin-bacterium interrelationships, and environmental factors influencing activity. Journal of Bacteriology 82, 940-949.

COOK, M. K., Blackford, V. L., RobBins, M. L. \& PARR, L. W. (1953). An investigation of the antibacterial spectrum of colicines. Antibiotics and Chemotherapy 3, 195-202.

FARKAS-Himsley, H. \& Seyfried, P. L. (1963a). Lethal biosynthesis of a bacteriocin, vibriocin, by $V$. comma. I. Conditions affecting its production and detection. Canadian Journal of Microbiology 9, 329-338.

Farkas-Himsley, H. \& Seyfried, P. L. (1963 b). Lethal biosynthesis of a bacteriocin, vibriocin, by V. comma. II. Vibriocin production and sensitivity in relation to redox potentials and streptomycin resistance. Canadian Journal of Microbiology 9, 339-343.

FredericQ, P. (1957). Colicins. Annual Review of Microbiology II, 7-23.

Gratia, A. (I925). Sur un remarquable exemple d'antagonisme entre deux souches de colibacille. Comptes rendus des séances de la Société de biologie 93, 1040-104I.

Halliwell, G. (1957). Cellulolytic preparations from microorganisms of the rumen and from Myrothecium verrucaria. Journal of General Microbiology 17, I66-I 83.

HaLliwell, G. (1965). Hydrolysis of fibrous cotton and reprecipitated cellulose by cellulolytic enzymes from soil micro-organisms. Biochemical Journal 95, 270-28I.

Hamon, Y. (1964). Les bacteriocines. Annals de L'Institut Pasteur 107, (Suppl. 5), i 8-53.

Hamon, Y. \& Peron, Y. (1962). Ėtude du pouvoir bactériocinogène dans le genre Listeria. I. Proprietés générales de ces bactériocines. Annals de L'Institut Pasteur 103, 876-889.

Herschmann, H. R. \& Helinski, D. R. (I967). Purification and characterization of colicin $\mathrm{E}_{2}$ and colicin $\mathrm{E}_{3}$. The Journal of Biological Chemistry 242, 5360-5368.

Holland, I. B. \& RoBerts, C. F. (1964). Some properties of a new bacteriocin formed by Bacillus megaterium. Journal of General Microbiology 3r, 27I-285.

Hughes, D. E. (195I). A press for disrupting bacteria and other micro-organisms. British Journal of Experimental Pathology 32, 97-109.

IVANòvics, G. (1962). Bacteriocins and bacteriocin-like substances. Bacteriological Reviews 26, I08-118.

JACob, F., Lwoff, A., Siminovitch, A. \& Wollman, E. (1953). Définition de quelques termes relatifs à la lysogenie. Annals de L'Institut Pasteur 84, 222-224.

JAYAWARDENe, A. \& FARKas-Himsley, H. (I969). Vibriocin: a bacteriocin from Vibrio comma. I. Production, purification, morphology and immunological studies. Microbios I, 87-98.

KutTNER, A. G. (1966). Production of bacteriocins by group A streptococci with special reference to the nephritogenic types. Journal of Experimental Medicine 124, 279-291.

ReEves, P. R. (1965). The bacteriocins. Bacteriological Reviews 29, 25-46.

StICKLeR, D. J., TuCKeR, R. G. \& KAY, D. (1965). Bacteriophage-like particles released from Bacillus subtilis after induction with hydrogen peroxide. Virology 26, I42-I45.

TAKEYA, K. \& SHIMODORI, S. (1969). New method for the detection of a lethal factor in vibrios. Journal of Bacteriology 99, 339-340.

TChan, Y. T. \& Guintini, J. (1950). Action antagoniste chez les Cytophagaceae. Annals de l'Institut Pasteur 78, 415-416.

Timmis, K. (1972). Purification and characterization of colicin D. Journal of Bacteriology rog, 12-20. 